\title{
AIKUISKASVATUS 10 VUOTTA
}

A ikuiskasvatus -lehti on nyt ilmestynyt 10 vuotta. Se merkitsee, että neljäkymmentä lehteä on nähnyt päivänvalon ja lähes 2000 sivua tiukkaa asiaa aikuiskasvatuksesta on tarjottu lukijoiden sulateltavaksi. Vaikka 10 vuotta on sinällään varsin lyhyt ajanjakso, niin melko paljon siinäkin ajassa on ehtinyt tapahtua suomalaisessa aikuiskasvatuksessa. Näin voi päätellä jo lehden vanhoja numeroita pintapuolisestikin selailemalla.

K oska jonkin toiminnan historian lähtökohtien tuntemus auttaa ymmärtämään sen nykytilaa, sallittakoon tässä yhteydessä lyhyt katsaus lehden perustamisvaiheisiin. Kansanvalistusseuran pedagoginen johtaja Pentti Yrjölä esitti allekirjoittaneelle vuonna 1979, että Kansanvalistusseura ja Aikuiskasvatuksen Tutkimusseura alkaisivat yhdessä toimittaa aikuiskasvatuksen ajankohtaisista tapahtumista kertovaa tiedotuslehteä. Virikkeen tähän antoi tuolloin ilmestynyt "Pohjoismainen aikuiskasvatuslehti", jonka kautta suomalaiset saivat usein vasta tietää, mitä Suomen ja muiden pohjoismaiden aikuiskasvatuksessa kulloinkin tapahtui. Olimme yhtä mieltä siitä, että Suomeen pitäisi perustaa oma julkaisu, jossa aikuiskasvattajille voitaisiin tiedottaa $\mathrm{mm}$. tuolloin aktiivissa vaiheessa olleesta alan valtakunnallisesta kehittämistyöstä ja keskustella siihen liittyvistä ongelmista. Lehdessä voitaisiin käsitellä myös muita aikuiskasvatuksen teoreettisia ja käytännöllisiä kysymyksiä. Päätimme kumpikin tahollamme ottaa lehtihankkeen ajaaksemme. Siitä keskusteltiin vuoden 1979 ja 1980 aikana useaan kertaan Aikuiskasvatuksen Tutkimusseuran ja Kansanvalistusseuran päättävissä elimissä. Tutkimusseuran johtokunta totesi lokakuussa 1979, ettei seura ole kiinnostunut tiedotuslehden toimittamisesta, mutta sen sijaan se olisi kiinnostunut alan tieteellisen aikakauslehden toimittamisesta yhteistyössä Kansanvalistusseuran kanssa. Seura katsoi, ettei omalle tiedotuslehdelle olisi riittäviä toimintaedellytyksiä, koska Pohjoismainen aikuiskasvatuslehti täytti tuolloin ainakin osittain tällaisen tarpeen. Mainittakoon, että ko. julkaisu lopetti toimintansa 1980-luvun puolessa välissä. Erilaisten vaihtoehtojen pohdiskelun jälkeen asettui myös Kansanvalistusseura marraskuussa 1980 tieteellisen lehden kannalle. Näin lehden toimittaminen saattoi alkaa. Lehden nimestä keskusteltiin
Aikuiskasvattaja, Aikuiskoulutus ja Aikuiskasvatus. Lopulta päädyttiin yksimielisesti viimeksimainittuun nimiehdotukseen. Aikuiskasvatuksen ensimmäinen numero ilmestyi kesäkuussa 1981.

Akuvaiheessa monet epäilivät, että lehdelle A käy samalla tavoin kuin seurojen aikaisemmalle yhteiselle lehtihankkeelle vuosina 1948-54 ilmestyneelle 'Kansansivistykselle", jonka toimittaminen jouduttiin lopettamaan vähäiseksi jääneen tilaajamäärän ja lukijakunnan takia. Aikuiskasvatus -lehti jatkaa "'Kansansivistyksen" aloittamaa työtä. Yhteiskunnallinen tilanne on nyt tietysti aivan toinen, samoinkuin aikuisväestön opiskelutarpeet. Aikuiskasvatuksesta on tullut osa valtiollista koulutuspolitiikkaa ja -suunnittelua. Vapaan sivistystyön rinnalle on kehittynyt nopeasti laajentunut ammatillisen aikuiskoulutuksen sektori, jota on kehitetty voimakkaasti 80 -luvulla. Tämä näkyy myös lehden sisällössä, ehkä liikaakin. Lehdessä on käsitelty melko paljon myös muita koulutuspoliittisia kysymyksiä. Siinä on esitelty enenevässä määrin myös vaihtoehtoisia opetusja oppimisjärjestelyjä. Samoin laadulliset ja toimintatutkimukselliset lähestymistavat ovat yleistyneet. Tämä kehitys jatkuu edelleen. Arvofilosofisetkin kysymykset ovat olleet aina silloin tällöin esillä. Näyttää siltä, että 90-luvulla olisi tarvetta herättää enemmänkin keskustelua aikuiskasvatuksen arvoista ja päämääristä. Tällaiset kysymykset ovat jääneet 80-luvulla taka-alalle, kun aikuiskasvatusta on innolla valjastettu elinkeinoelämän vankkurien vetäjäksi.

Tuskin on liioiteltua sanoa, että Aikuiskasvatus -lehti on vakiinnuttanut asemansa suomalaisten tieteellisten aikakauslehtien joukossa. Se on saanut vuosittain apurahan Suomen Akatemialta tieteelliseen julkaisutoimintaan tarkoitetuista varoista ja on alan ainoa pohjoismainen tieteellinen aikakauslehti. Muualla Euroopassa ja "rapakon" takana vastaavia kyllä löytyy. Se miten Suomessa kyetään ylläpitämään tällaista lehteä, herättää aina ihmetystä pohjoismaisten kollegojen keskuudessa. Yksi selitys on tietysti se, että meillä on myös pitkäaikaisin alan korkeakoulutasoisen opetuksen ja tutkimuksen perinne.

Vaikka lehden tilaajakunta ei ole kovin suuri (noin 1700), se tuntuu kuitenkin melko uskolliselta ja vakiintuneelta. Vaikka emme ole tehneet lukijatutkimusta, jonkinlainen kuva 
lehden lukijoista ja tilaajista on toimitukselle muodostunut. Kantajoukon muodostavat vapaan sivistystyön ja ammatillisen aikuiskoulutuksen sektorilla toimivat päätoimiset hallinto-, suunnittelu- ja kehittämistehtävissä toimivat aikuiskasvattajat. Muut kasvatusalalla toimivat ovat myös nykyisin hyvin kiinnostuneita lehdestä. Jossain määrin lehteä ilmeisesti lukevat myös ne yhteiskuntatieteilijät, joilla on omakohtaisia kontakteja aikuiskasvatukseen tai joiden tutkimustoiminta liittyy jotenkin aikuisten opiskeluun. Myös alan opiskelijat ovat nykyisin lehden aktiivisia lukijoita ja tilaajia.

T ehden kirjoittajakunta on laajentunut L ilahduttavasti koko ajan. Alkuvaiheessa kirjoittajat olivat lähes yksinomaan aikuiskasvatuksen opettajia tai tutkijoita. He muodostavat tietysti edelleen kirjoittajien kantajoukon. Lehdessä esiintyvät entistä useammin myös muut kasvatustieteilijät, sosiologit, psykologit sekä erilaisissa opetus-, suunnittelu-, hallinto- tai kehittämistehtävissä toimivat työntekijät. Kirjoittajajoukon kirjavuus saattaa olla joskus ongelmallistakin. Yhteisen viitekehityksen puuttuminen voi aiheuttaa kommunikaatio- ja ymmärtämisongelmia. Näkisin lähestymistapojen runsauden kuitenkin pääasiassa positiivisena ja lehteä avartavana elementtinä. Erilaiset teoreettiset lähestymistavat monipuolistavat aikuiskasvatuksen ongelmanasetteluja ja niiden ratkaisuyrityksiä. Oman lisänsä lehden ilmeeseen ovat antaneet ulkomaiset kirjoittajat, joita on vuosien kuluessa esiintynyt lehden palstoilla kohtalaisen runsaasti. Onpa joidenkin kanssa muodostunut melko pysyväkin kirjoittajasuhde. On luonnollista, että lehdessä kirjoittavat enimmäkseen alan tutkijat tai korkeakouluissa työskentelevät. Kirjoittaminenhan kuuluu heidän ammattiinsa. Käytännön opetustyössä olevat uskaltautuvat vain harvoin kertomaan omista kokemuksistaan. On kuitenkin syytä muistaa että lehdessä on myös katsaus- ja keskusteluosastot, missä kuka tahansa voi kertoa kokemuksistaan tai tuoda esiin oman käsityksensä jostakin ajankohtaisesta asiasta.
Myös kirja-arvioinnit ja esittelyt ovat aina tervetulleita.

Kuten kaikilla muillakin soveltavan tieteen alueilla, vallitsee myös aikuiskasvatuksessa alan tutkijoiden ja ns. kentän välillä tietty jännite. Tämä on vaikuttanut koko ajan myös lehden toimittamiseen. Sekä lehden toimituskunnassa että -neuvostossa on jatkuvasti käyty keskustelua siitä, mikä tulisi olla teoreettisluonteisten ja käytännöllispainotteisten kirjoitusten osuus ja suhde lehdessä. Kentän edustajat ovat joskus syyttäneet lehteä liian "'teoreettiseksi", millä he ilmeisesti tarkoittavat sitä, että artikkelit ovat vaikeaselkoisia eikä niistä löydy konkreettisia ohjeita oman työn kehittämiseksi. Tämä pitää varmaan joskus paikkansa. Väitän kuitenkin, että Aikuiskasvatus on - verrattuna moneen muuhun tiedelehteen - varsin käytännönläheinen ja konkreettisiakin asioita pohdiskeleva. Tietysti jotkut artikkelit voivat olla vaikeasti avautuvia. Niin pitää mielestäni ollakin. Uusien asioiden ja näkemysten omaksuminen vaatii yleensä jonkin verran ponnistelua. Tästä huolimatta niihin paneutuminen maksaa useimmiten vaivan, jos ei muuten niin jonkinlaisena "aivovoimisteluna". Uuden oppiminen ja omaksuminen kuuluu myös aikuiskasvattajille.

Merkillepantavaa on, että käsikirjoitusten tarjonta on aikaisempiin vuosiin verrattuna runsasta. Kirjoituksia joudutaan nyt valikoimaan entistä enemmän. Vallitsevan markkinakäsityksen mukaan tämän pitäisi parantaa lehden laatua. Tulevaisuus näyttää, miten käy. Uusi tilanne asettaa joka tapauksessa lehden toimittajat vaativan tehtävän eteen. Heidän ja asiantuntijoiden tulee kiinnittää entistä enemmän huomiota artikkelien laatuun, eikä vain niiden mielenkiintoisuuteen ja ajankohtaisuuteen. Tämä lisää toimituksen työtä ja hidastaa jonkin verran tarjottujen kirjoitusten "läpivirtausta". Kun tuloksena on - toivottavasti - entistä laadukkaampi lehti, niin näihin ongelmiin on helppo suhtautua suomalaisella tyyneydellä. Aikuiskasvatus-lehti aloittaa uuden vuosikymmenen luottavaisin mielin.

JUKKA TUOMISTO 